\title{
EFFECT OF INTRAVENOUS CARDIAC GLYCOSIDES ON THE AQUEOUS HUMOUR DYNAMICS OF THE CAT* $\dagger$
}

\author{
BY \\ DAVID M. WARNER AND STEPHEN M. DRANCE $\ddagger$ \\ From the Department of Ophthalmology, Faculty of Medicine, University of British Columbia, Canada
}

\begin{abstract}
Previous investigation by Simon, Bonting, and Hawkins (1962) indicated that intravenous cardiac glycosides caused a significant fall in the rate of aqueous humour formation in the cat eye. Langham (1963), using rabbits and cats, and Becker (1963), using rabbits, were not able to demonstrate this effect. Becker, using an intravitreal injection of cardiac glycosides, was able to demonstrate a fall in intraocular pressure. The use of cardiac glycosides in the clinical treatment of glaucoma has been reported by Simon and others (1962), who were able to demonstrate a measurable fall in the intra-ocular pressure. Smith and Mickatavage (1963) showed that topical cardiac glycosides caused a measurable, though slight, fall in intraocular pressure.

This report concerns experimental work on cats. The method used by Simon and others (1962) has been substantially repeated.
\end{abstract}

\section{Method}

Adult female cats were anaesthetized with intraperitoneal Nembutal $(30 \mathrm{mg} . / \mathrm{kg}$.$) . Additional$ intravenous Nembutal was administered during the course of the experiment if the depth of anaesthesia was not considered to be adequate. The head was not immobilized but was allowed to rest lightly on a platform so that the diaphragms of the transducers, the anterior chamber, and the heart were all on the same horizontal plane. The femoral artery and vein were cannulated using No. 190 and 90 polyethylene tubing respectively. Continuous pressure recordings were made, using Statham high and low level pressure transducers. Both anterior chambers were cannulated close to the limbus using a 25-gauge needle connected by short lengths of No. 90 polyethylene tubing to two Statham low-pressure transducers. The arterial and venous systems were filled with bubble-free heparinized normal saline. The anterior chamber systems were filled with bubblefree phosphate buffer pH 6.95. Continuous arterial, venous, and anterior chamber pressure tracings were made, using a Grass Polygraph with a SP1.K low-level DC pre-amplifier and 5E driver amplifiers.

After cannulation of the anterior chambers, a period of 15 to 20 minutes was allowed to elapse while the intra-ocular pressure reached a steady-state level. At this stage a reservoir connected to the anterior chamber was lowered, reducing the intra-ocular pressure by approximately half. The aqueous drainage was allowed to continue for one minute with the pressure maintained at this level. The reservoir was then disconnected and the intra-ocular pressure allowed to rise to its

* Received for publication August 18, 1965.

+ This study was supported by Federal-Provincial Health Grant No. 609-7-64.

₹ Address for reprints: 2550 Willow Street, Vancouver 9, B.C., Canada.

54 
pre-existing level (Fig. 1). The slope of this curve was measured in $\mathrm{mm}$. $\mathrm{Hg}$ per minute and taken as an index of the aqueous inflow. When steady-state pressure levels were once again obtained, a slow intravenous injection of the appropriate cardiac glycoside was given. Digoxin in doses between 0.075 and $0.13 \mathrm{mg} . / \mathrm{kg}$. and ouabain in doses between 0.05 and $0.10 \mathrm{mg}$. $/ \mathrm{kg}$. were used. The anterior chamber systems were then allowed to remain undisturbed for a period of 30 to 45 minutes during which time a further steady level of intra-ocular pressure was reached. Inflow rate was then again measured (Fig. 2).

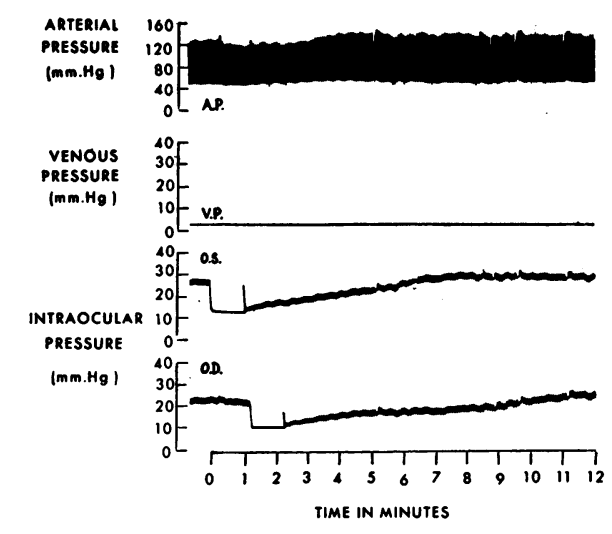

Fig. 1.-Arterial pressure, venous pressure, and intra-ocular pressure tracings before administration of intravenous digoxin. Inflow rates derived from recovery rate of intraocular pressure, measured in $\mathrm{mm}$. $\mathrm{Hg} / \mathrm{min}$.

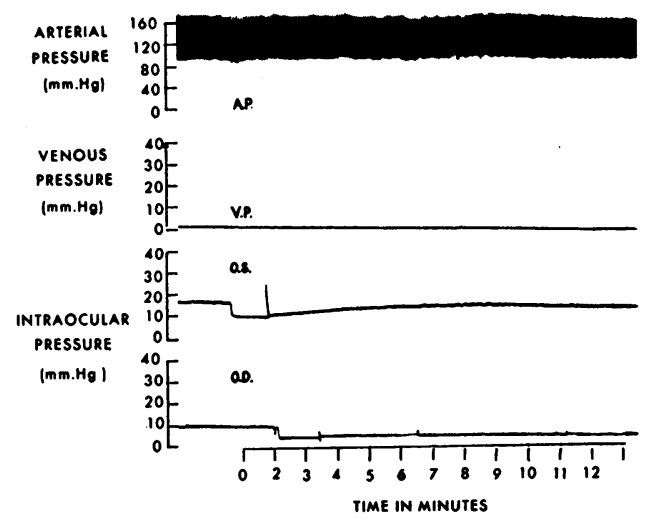

Fig. 2.-Arterial pressure, venous pressure, and intra-ocular pressure tracings 21 minutes after injection of $0.10 \mathrm{mg} . / \mathrm{kg}$. intravenous digoxin. Inflow rates derived from recovery rate of intraocular pressure, measured in $\mathrm{mm} . \mathrm{Hg} / \mathrm{min}$.

Estimations of outflow and scleral rigidity were made before and after administration of cardiac glycoside, using the methods described by Langham and Eakins (1964) and Eisenlohr and Langham (1962). The results of these estimates have not been included in this paper.

As a control six cats were used repeating the technique described above but without the injection of cardiac glycosides.

\section{Results}

The inhibition of aqueous inflow produced by cardiac glycosides was estimated by a change in slope of the recovery of intra-ocular pressure measured in $\mathrm{mm}$. $\mathrm{Hg}$ per minute. Tables I and II (opposite) show that there has been an inhibition of 48 per cent. after the administration of digoxin and of 46 per cent. after that of ouabain. This inhibition was accompanied by a fall in the steady-state intra-ocular pressure of 17 per cent. in the digoxin studies and 15.5 per cent. in the ouabain studies. During the experiments it was noted that variations in systemic blood pressure were reflected in the intra-ocular pressure and a ratio was derived which showed that a rise in blood pressure of $11 \mathrm{~mm}$. $\mathrm{Hg}$ caused a rise of $1 \mathrm{~mm}$. $\mathrm{Hg}$ in the intra-ocular pressure. Applying the blood pressure/intra-ocular pressure ratio to the data obtained, it can be seen that the direction of change in the blood pressure would have tended to increase intra-ocular pressure, but that in spite of this a fall in the intra-ocular pressure was obtained with digoxin and ouabain.

The control series show that there was a 50 per cent. inhibition of recovery rate of intra-ocular pressure (Table III, overleaf). There was a fall in the steady-state intra-ocular pressure of 33 per cent. and a slight rise in the blood pressure during the course of the experiment. 
TABLE I

Effect of Intravenous Administration of Digoxin on Aqueous Humour DYNAMICS IN THE CAT

\begin{tabular}{|c|c|c|c|c|c|c|c|c|c|c|c|c|c|}
\hline \multirow{2}{*}{$\begin{array}{c}\text { Date of } \\
\text { Experiment } \\
\text { (1964) }\end{array}$} & \multirow{2}{*}{$\begin{array}{c}\text { Dosage } \\
\text { of Drug } \\
\text { (mg./kg.) }\end{array}$} & \multirow[t]{2}{*}{ Eye } & \multicolumn{2}{|c|}{$\begin{array}{c}\text { Recovery Rate of } \\
\text { IOP (mm. Hg/min) }\end{array}$} & \multirow{2}{*}{$\begin{array}{c}\text { Inhi- } \\
\text { bition } \\
\text { (per } \\
\text { cent.) }\end{array}$} & \multicolumn{2}{|c|}{$\begin{array}{l}\text { Equilibrium } \\
\text { Value of IOP } \\
\text { (mm. Hg) }\end{array}$} & \multirow{2}{*}{$\begin{array}{c}\triangle \mathrm{IOP} \\
\text { (per } \\
\text { cent.) }\end{array}$} & \multicolumn{2}{|c|}{$\begin{array}{l}\text { Venous Pressure } \\
\text { (mm. Hg) }\end{array}$} & \multicolumn{3}{|c|}{ Mean Blood Pressure } \\
\hline & & & Before & After & & Before & After* & & Before & After* & Before & After* & $\triangle$ B.P. \\
\hline May 8 & $0 \cdot 10$ & $\begin{array}{l}\mathbf{R} \\
\mathbf{L}\end{array}$ & $\begin{array}{l}1 \cdot 0 \\
2 \cdot 0\end{array}$ & $\begin{array}{l}0.1 \\
0.6\end{array}$ & $\begin{array}{l}90 \\
70\end{array}$ & $\begin{array}{r}16 \cdot 0 \\
21 \cdot 0\end{array}$ & $\begin{array}{r}9 \cdot 8 \\
16 \cdot 5\end{array}$ & $\begin{array}{l}38 \cdot 7 \\
21 \cdot 4\end{array}$ & $1 \cdot 0$ & $1 \cdot 0$ & 90 & 130 & 40 \\
\hline May 14 & $0 \cdot 13$ & $\begin{array}{l}\mathbf{R} \\
\mathbf{L}\end{array}$ & $\begin{array}{l}0 \cdot 2 \\
0 \cdot 3\end{array}$ & $\begin{array}{l}0.1 \\
0.2\end{array}$ & $\begin{array}{l}50 \\
33\end{array}$ & $\begin{array}{l}10 \cdot 0 \\
13 \cdot 5\end{array}$ & $\begin{array}{r}7.0 \\
11.5\end{array}$ & $\begin{array}{l}30 \cdot 0 \\
14.8\end{array}$ & 0.0 & $-1 \cdot 0$ & 70 & 120 & 50 \\
\hline May 20 & 0.075 & $\underset{\mathbf{L}}{\mathbf{R}}$ & $\begin{array}{l}0.9 \\
1 \cdot 2\end{array}$ & $\begin{array}{l}0 \cdot 3 \\
0 \cdot 4\end{array}$ & $\begin{array}{l}66 \\
66\end{array}$ & $\begin{array}{l}24 \cdot 0 \\
20 \cdot 0\end{array}$ & $\begin{array}{l}20.0 \\
17.0\end{array}$ & $\begin{array}{l}16 \cdot 7 \\
15.0\end{array}$ & $9 \cdot 0$ & $11 \cdot 0$ & 63 & 98 & 35 \\
\hline June 3 & $0 \cdot 10$ & $\begin{array}{l}\mathbf{R} \\
\mathbf{L}\end{array}$ & $\overline{0 \cdot 2}$ & $\overline{0 \cdot 2}$ & $\overline{0}$ & $\overline{14 \cdot 5}$ & $\overline{10 \cdot 5}$ & $2 \overline{27 \cdot 6}$ & $1 \cdot 5$ & - & 136 & 140 & 4 \\
\hline June 10 & $0 \cdot 10$ & $\begin{array}{l}\mathbf{R} \\
\mathbf{L}\end{array}$ & $\begin{array}{l}0.2 \\
0.3\end{array}$ & $0 \cdot 1$ & $\underline{50}$ & $\begin{array}{l}10 \cdot 2 \\
13 \cdot 0\end{array}$ & $\begin{array}{r}9 \cdot 8 \\
11 \cdot 0\end{array}$ & $\begin{array}{l}39 \cdot 2 \\
15 \cdot 4\end{array}$ & 0.0 & - & 52 & 62 & 10 \\
\hline June 18 & $0 \cdot 10$ & $\begin{array}{l}\mathbf{R} \\
\mathbf{L}\end{array}$ & $\begin{array}{l}0 \cdot 7 \\
0 \cdot 7\end{array}$ & $\begin{array}{l}0 \cdot 7 \\
0 \cdot 4\end{array}$ & $\begin{array}{r}0 \\
43\end{array}$ & $\begin{array}{l}11 \cdot 0 \\
14 \cdot 2\end{array}$ & $\begin{array}{l}10 \cdot 5 \\
14 \cdot 5\end{array}$ & $\begin{array}{r}4 \cdot 5 \\
+2 \cdot 1\end{array}$ & $1 \cdot 0$ & $0 \cdot 6$ & 101 & 115 & 14 \\
\hline July 6 & 0.075 & $\begin{array}{l}\mathbf{R} \\
\mathbf{L}\end{array}$ & $\begin{array}{l}0.4 \\
0.6\end{array}$ & $\begin{array}{l}0.2 \\
0.2\end{array}$ & $\begin{array}{l}50 \\
66\end{array}$ & $\begin{array}{l}13 \cdot 5 \\
14 \cdot 0\end{array}$ & $\begin{array}{l}13 \cdot 5 \\
14 \cdot 0\end{array}$ & $\begin{array}{l}0.0 \\
0.0\end{array}$ & 1.5 & $0 \cdot 2$ & 72 & 80 & 8 \\
\hline \multicolumn{3}{|l|}{ Average } & 0.67 & $0 \cdot 30$ & $48 \cdot 7$ & 14.9 & $12 \cdot 7$ & $17 \cdot 0$ & $2 \cdot 0$ & $2 \cdot 4$ & $83 \cdot 4$ & $106 \cdot 4$ & $23 \cdot 0$ \\
\hline \multicolumn{3}{|c|}{ Standard Deviation } & \pm 0.51 & $\pm 0 \cdot 19$ & $\pm 27 \cdot 1$ & $\pm 4 \cdot 3$ & $\pm 4 \cdot 4$ & $\pm 13 \cdot 9$ & & & & & \\
\hline
\end{tabular}

* Readings taken 15 minutes after injection of digoxin.

TABLE II

Effect of Intravenous Administration of Ouabain on Aqueous Humour DYNAMICS IN THE CAT

\begin{tabular}{|c|c|c|c|c|c|c|c|c|c|c|c|c|}
\hline \multirow[t]{2}{*}{$\begin{array}{c}\text { Date of } \\
\text { Experiment }\end{array}$} & \multirow{2}{*}{$\begin{array}{c}\text { Dosage } \\
\text { of Drug } \\
\text { (mg./kg.) }\end{array}$} & \multicolumn{2}{|c|}{$\begin{array}{l}\text { Recovery Rate } \\
\text { of IOP } \\
\text { (mm. Hg/min.) }\end{array}$} & \multirow{2}{*}{$\begin{array}{c}\text { Inhibi- } \\
\text { tion } \\
\text { (per } \\
\text { cent.) }\end{array}$} & \multicolumn{2}{|c|}{$\begin{array}{c}\text { Equilibrium } \\
\text { Value of IOP } \\
\text { (mm. Hg) }\end{array}$} & \multirow{2}{*}{ 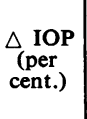 } & \multicolumn{2}{|c|}{$\begin{array}{l}\text { Venous Pressure } \\
(\mathrm{mm} . \mathbf{H g})\end{array}$} & \multicolumn{3}{|c|}{$\begin{array}{l}\text { Mean Blood Pressure } \\
\text { (mm. Hg) }\end{array}$} \\
\hline & & Before & After & & Before & After* & & Before & After & Before & After* & $\triangle$ B.P. \\
\hline February 18 & $\cdot 10$ & & & & 23.0 & $19 \cdot 5$ & $15 \cdot 2$ & & & 126 & 135 & 9 \\
\hline February 19 & .07 & $0 \cdot 12$ & $0 \cdot 10$ & $16 \cdot 7$ & $15 \cdot 3$ & $13 \cdot 8$ & $9 \cdot 8$ & & & 102 & 120 & 18 \\
\hline February $20 \dagger$ & $\cdot 10$ & 0.33 & 0.56 & $69 \cdot 9$ & $8 \cdot 0$ & $10 \cdot 0$ & $25 \cdot 0$ & & & 97 & 124 & 27 \\
\hline March 3 & .05 & 0.47 & $0 \cdot 18$ & $61 \cdot 7$ & $28 \cdot 0$ & $24 \cdot 4$ & $12 \cdot 8$ & & & 120 & 160 & 40 \\
\hline March 4 & .04 & 0.40 & $0 \cdot 18$ & $55 \cdot 0$ & $26 \cdot 0$ & $20 \cdot 6$ & $20 \cdot 8$ & & & 140 & 152 & 12 \\
\hline March 6 & .05 & 0.84 & 0.38 & $50 \cdot 5$ & $17 \cdot 5$ & $14 \cdot 2$ & $18 \cdot 8$ & & & 98 & 126 & 28 \\
\hline \multicolumn{2}{|l|}{ Average } & 0.46 & 0.21 & $46 \cdot 0$ & $22 \cdot 0$ & $18 \cdot 5$ & $15 \cdot 5$ & & & $117 \cdot 2$ & $138 \cdot 6$ & 21.4 \\
\hline \multicolumn{2}{|c|}{ Standard Deviation } & $\pm 0 \cdot 29$ & \pm 0.21 & $\pm 20 \cdot 1$ & $\pm 5 \cdot 4$ & $\pm 4 \cdot 5$ & $\pm 4 \cdot 4$ & & & & & \\
\hline
\end{tabular}

* Readings taken 15 minutes after injection of ouabain.

+ Results of experiment, February 20 , not used in calculations of final totals, averages, and standard deviations because of variations in blood pressure during the initial recovery rate estimations.

\section{Discussion}

The results obtained were comparable to those obtained by Simon and others (1962). It was demonstrated that, with the administration of cardiac glycosides in the anaesthetized cat, there was a fall in the steady-state intra-ocular pressure with a fall in recovery rate of intra-ocular pressure and that this was accompanied by a rise in the mean blood pressure in the experimental series. The control series, without cardiac glycoside, showed that, in the anaesthetized cat, there is a decrease in the 
TABLE III

Aqueous Dynamics of the Cat without Intravenous Administration of CARDiaC Glycosides

\begin{tabular}{|c|c|c|c|c|c|c|c|c|c|c|c|c|}
\hline \multirow[t]{2}{*}{$\begin{array}{c}\text { Date of } \\
\text { Experiment }\end{array}$} & \multirow[t]{2}{*}{ Eye } & \multicolumn{2}{|c|}{$\begin{array}{l}\text { Recovery Rate } \\
\text { of IOP } \\
\text { (mm. Hg/min.) }\end{array}$} & \multirow{2}{*}{$\begin{array}{c}\text { Inhibi- } \\
\text { tion } \\
\text { (per } \\
\text { cent.) }\end{array}$} & \multicolumn{2}{|c|}{$\begin{array}{l}\text { Equilibrium } \\
\text { Value of IOP } \\
\text { (mm. Hg) }\end{array}$} & \multirow{2}{*}{$\underset{\begin{array}{c}\text { (per } \\
\text { cent.) }\end{array}}{\Delta \text { IOP }}$} & \multicolumn{2}{|c|}{$\begin{array}{l}\text { Venous Pressure } \\
\text { (mm. Hg) }\end{array}$} & \multicolumn{3}{|c|}{$\begin{array}{l}\text { Mean Blood Pressure } \\
\text { (mm. Hg) }\end{array}$} \\
\hline & & Before & After & & Before & After & & Before & After & Before & After & $\triangle$ B.P. \\
\hline September 2 & $\begin{array}{l}\mathbf{R} \\
\mathbf{L}\end{array}$ & $\begin{array}{l}1 \cdot 11 \\
0.94\end{array}$ & $\begin{array}{l}0.53 \\
1.05\end{array}$ & $\begin{array}{l}52.3 \\
11.7 *\end{array}$ & $\begin{array}{l}22 \cdot 5 \\
24 \cdot 0\end{array}$ & $\begin{array}{l}12.5 \\
19.0\end{array}$ & $\begin{array}{l}44.4 \\
20.8\end{array}$ & $4 \cdot 5$ & $1 \cdot 0$ & 84 & 86 & +2 \\
\hline September 4 & $\begin{array}{l}\mathbf{R} \\
\mathbf{L}\end{array}$ & $\begin{array}{l}2.49 \\
1.83\end{array}$ & $\begin{array}{l}1.90 \\
1.35\end{array}$ & $\begin{array}{l}23 \cdot 7 \\
28 \cdot 2\end{array}$ & $\begin{array}{l}32 \cdot 0 \\
31.0\end{array}$ & $\begin{array}{l}23 \cdot 0 \\
25.0\end{array}$ & $\begin{array}{l}28.1 \\
19 \cdot 4\end{array}$ & $1 \cdot 5$ & -0.5 & 122 & 108 & -14 \\
\hline September 8 & $\begin{array}{l}\mathbf{R} \\
\mathbf{L}\end{array}$ & $\begin{array}{l}0.44 \\
0.63\end{array}$ & $\begin{array}{l}0.33 \\
0.38\end{array}$ & $\begin{array}{l}25 \cdot 0 \\
39 \cdot 3\end{array}$ & $\begin{array}{l}20 \cdot 5 \\
22 \cdot 5\end{array}$ & $\begin{array}{l}15.0 \\
18.5\end{array}$ & $\begin{array}{l}26 \cdot 8 \\
17 \cdot 7\end{array}$ & $2 \cdot 5$ & 1.5 & 66 & 68 & +2 \\
\hline September 16 & $\begin{array}{l}R \\
\mathbf{L}\end{array}$ & $\begin{array}{l}2.00 \\
2.05\end{array}$ & $\begin{array}{l}0.44 \\
0.44\end{array}$ & $\begin{array}{l}78 \cdot 0 \\
78 \cdot 5\end{array}$ & $\begin{array}{l}35 \cdot 0 \\
36 \cdot 0\end{array}$ & $\begin{array}{l}15.0 \\
14.0\end{array}$ & $\begin{array}{l}57 \cdot 1 \\
61 \cdot 1\end{array}$ & 5.0 & $3 \cdot 5$ & 120 & 108 & -12 \\
\hline September 17 & $\begin{array}{l}\mathbf{R} \\
\mathbf{L}\end{array}$ & $\begin{array}{l}0.61 \\
0.96\end{array}$ & $\begin{array}{l}0.25 \\
0.25\end{array}$ & $\begin{array}{l}59.0 \\
73.8\end{array}$ & $\begin{array}{l}20.0 \\
26.0\end{array}$ & $\begin{array}{l}14.0 \\
19.0\end{array}$ & $\begin{array}{l}30.0 \\
26.9\end{array}$ & $3 \cdot 0$ & $2 \cdot 0$ & 108 & 132 & +24 \\
\hline \multicolumn{2}{|l|}{ Average } & $1 \cdot 31$ & 0.69 & 50.9 & $27 \cdot 0$ & $17 \cdot 5$ & $33 \cdot 2$ & $3 \cdot 3$ & 1.5 & $100 \cdot 0$ & $100 \cdot 4$ & +0.4 \\
\hline \multicolumn{2}{|c|}{ Standard Deviation } & $\pm 0 \cdot 72$ & \pm 0.56 & $\pm 22 \cdot 7$ & $\pm 5 \cdot 9$ & $\pm 4 \cdot 2$ & $\pm 15 \cdot 5$ & & & & & \\
\hline
\end{tabular}

* Not included in the calculation of the average and standard deviation.

recovery rate of the intra-ocular pressure and a decrease in the steady-state intraocular pressure, but that this is associated with a slight rise in blood pressure.

It would appear that the effect of intravenous cardiac glycosides in cats reported by Simon and others (1962), namely, a fall in intra-ocular pressure and in recovery rate of the intra-ocular pressure, cannot be attributed to cardiac glycosides alone. It has been demonstrated in control series in this investigation that the major part of the decrease in intra-ocular pressure and inflow rate could be attributed to the prolonged Nembutal anaesthesia, which is associated in cats with: (1) a minimal rise in the systolic blood pressure, (2) a fall in a steady-state intra-ocular pressure, and (3) a decrease in the recovery rate of intra-ocular pressure.

\section{Summary}

The alteration in the inflow rates of aqueous humour in the cat eye as a result of intravenous digoxin or ouabain were studied. In vivo experiments in the cat showed that the intravenous administration of digoxin, 0.075 to $0.13 \mathrm{mg} . / \mathrm{kg}$., caused an inhibition of aqueous inflow by 48 per cent. measured by the slope of the pressure recovery curve after aqueous drainage. Ouabain given in doses of 0.046 to $0 \cdot 10$ $\mathrm{mg} . / \mathrm{kg}$. caused an inhibition of aqueous inflow by 45 per cent. It was shown in the control series, where no cardiac glycosides were used, that there was an inhibition of aqueous inflow under comparable circumstances of 50.9 per cent. Blood pressure and venous pressure were monitored throughout the experiments.

BECKER, B. (1963). Invest. Ophthal., 2, 325.

\section{REFERENCES}

EISENLOHR, J. E., and LANGHAM, M. E. (1962). Ibid., 1, 63.

Langham, M. E. (1963). Amer. J. Ophthal., 56, 470. and Eakins, K. E. (1964). J. Pharmacol., 144, 421.

Simon, K. A., Bonting, S. L., and Hawkins, N. M. (1962). Exp. Eye Res., 1, 253.

Smith, J. L., and Mickatavage, R. C. (1963). Amer. J. Ophthal., 56, 889. 